\title{
A Research on the Change of Female Characters Portrayed in Science Fiction Films and Its Social Influences
}

\author{
Wenjia Tang
}

\begin{abstract}
The content of science fiction films is the artistic reflection to society reality, and they are the proper context to discuss the future living situation of human beings. Under the assumption of science fiction topic, the relationship between genders is required to be re-evaluated and redefined from a new perspective in the contemporary generation. In the recent market of science fiction films, the majority of the total is produced by western countries and then exhibited globally. Therefore, this essay uses classic English-speaking science fiction films as the research sample to review the depiction of female characters during their development history. This essay will clarify the changes in the positioning and performance of female characters in this genre of film through horizontal and vertical comparisons, and also contrast this change to several feminism trends to explore the reflection and feedback of the sci-fi film as a social and cultural phenomenon on the reality of the western world. Meanwhile, on this basis, this essay will also discuss how sci-fi films can guide and change the audience in a practical way, for example, showing positive female images to help more women to break the stereotype and actively participate in science-related work or study.
\end{abstract}

Index Terms - Female characters, feminism, gender, science fiction films.

\section{INTRODUCTION}

As a genre of film, science fiction films are made up of collages of surreal science and technology elements and use well-established scientific ideas to form social backgrounds. As a concept of the "utopia" of the real world, science fiction films place people's expectation of the future world and their reflections on the new interpersonal relationship.

But even though science fiction works call for more advanced ideas, there are still some gender stereotypes in their context. Many works view women traditionally as "the other" and misinterpret them [1]. Meanwhile, the expectation of sci-fi films to break the stereotype and set up new models for gender issue contemporarily emerged. This essay argues that popular modern sci-fi films, whose plots are developed based on realistic progress, are attempting to portray a real and vivid image of female characters to give response to the audience. This particular genre of film can help to extend the boundary of the conception of gender generally.

This essay will be divided into two sections: firstly, this essay will base on the science fiction films themselves to establish the history of their development and explore how the female characters in science fiction films earn their rights to speak step by step. In this part, the essay will also examine

Manuscript received April 05, 2019; revised July 10, 2019.

Wenjia Tang is with University College London, United Kingdom (e-mail: wenjia.tang.18@ucl.ac.uk). the impact of science fiction films on society from positive perspectives. In the second section, the limitation of sci-fi films on represent of female will be discussed according to the characteristic of the genre and the box office.

\section{LITERATURE REVIEW}

In western countries, many related pieces of research have emerged due to a large number of sci-fi films produced in the market recently. The discussion of film and gender issues has never stopped: feminists demand that works of arts correctly represent female images and appeal for true equality. At the end of the last century, science fiction films began to try to challenge traditional stereotypes and gender concepts, which attracted more scholars to study the role of female characters in those sci-fi works. [1] believes the worldview of science fiction creates possibilities for building new gender relationships and sets an example for gender relations in society. This idea is a good expression of how artwork can affect reality. However, people should be more conscious of how big difference sci-fi films can make due to how many audiences they can reach. [2] shares the same ground with [1]. [2] mentions that the relationship between audiences and characters in films will also affect the expressiveness and influence of the films themselves in reality from a perspective of phenomenology. [2] also connects the audience in cinemas with the role inside the screen and brings the audience's reception and understanding of the content into consideration. This suggests the interaction between science fiction films and the audience's behaviors.

Similarly, [3] point out that the performance of the female scientists in episodes will have a psychological impact on the audience's choice of career. Since scientists are widely depicted in sci-fi films, it is worthy of paying attention to that specific field of career. However, the research on sci-fi films should go beyond the limitation of the genre itself and have a more comprehensive analysis of different female images.

\section{METHODOLOGY}

Firstly, this essay will first adopt the method of literary analysis. It establishes a preliminary understanding of the issue by reading the discussions among different scholars in the field, clarifying their research objects and sorting out their views. Furthermore, this essay will sort out the relationship between the views of different critics to explore which are the conclusions they have in common or disagree. Samples of films will be used to combine these views to evaluate how useful they are.

Secondly, the essay will also adopt the method of 
analogical reasoning, which divides the female characters showed in science fiction films according to their role types, functions and positioning. This essay will horizontally compare similar and different expressions between different roles in groups.

Because of the domination of mainstream English-speaking films in the global film market, film practices in other parts of the world are also influenced by their principles in narrative and character shaping style. Therefore, this essay will combine above theoretical results of different researchers and use samples of various types of female characters created by British and American science fiction films, to sort out the changes happened during the history of sci-fi films. Additionally, some social thought of trends will be combined as the background of these films as well for exploring the depth and breadth of expression of female characters.

\section{The Changing Images of Female Roles In the History OF SCIENCE FICTION FILMS AND THE POSITIVE IMPACTS}

When sci-fi themes exceed the limits of reality and begin to look into the future's possibilities for the development, the audience also expects new relationships to be redefined in the modern era. Feminists are looking forward to seeing more realistic and representative roles in science fiction films. These expectations are understandable: Firstly, in the context of science fiction films, the large-scale use of machines and advances in scientific research have reduced the absolute strength difference between the two genders. Secondly, with the development of feminist movements, there has been continuous appealing for more equal sexual relations. The films received influence from this ideological trend and began to change their original stereotypes.

However, it takes time to complete from the birth of an ideological trend to the fact that it is beginning to change social reality. Although science fiction films are seen as an idealised social environment to discuss the development of gender issues and the future direction; they still need a stage of development to improve the portrayal and display of women's roles.

In the development history of science fiction films over a hundred years, along with the influence of social movements, female characters have gradually emerged from male-dominated discourse power, from being misunderstood as "irrelevant" to being protected and appreciated as "dolls". And then, they finally show their characteristics and social values from more perspectives and are more broadly representative of the women's role in the society at that time. The changes of these female characters in films also cater to their values and status that are gradually recognised in society.

In the early $20^{\text {th }}$-century sci-fi films, female characters were seen as the source of terror and the incarnation of sin. For example, in Frankenstein (1910), The Bride of Frankenstein (1935) and Dr Jekyll and Mr Hyde (1931), female characters were all represented by evil. The former series tells about a bride who was spliced by a scientist and transformed into a zombie; the latter portrayed a debauched woman who evoked the leading character's vicious personality. This period was the time when liberal feminism prevailed in the western world. Women went to fight for their political and legal rights [4]. Many laws were created to protect the rights of women in reality due to their efforts. Unfortunately, this ideological trend did not affect the production of films. Much of the metaphor for women's sarcastic and defamatory appears in early science fiction films as mentioned above: men seem to be always afraid that behind the beautiful appearance of a woman, a terrible variation is hidden.

By the end of the 20th century, Hollywood films had flourished, and the fast-paced, stimulating films became the mainstream. Science fiction works also follow this trend, changed from the early style of terror to adventure stories. However, in these stories, female characters became the partners of male characters. They appear as a housewife or a lover accompanied by male characters.

In 1977, the first Star Wars film was released and a beautiful lady Leia Organa Solo left her mark in the hearts of many audiences. In this film, Princess Leia appears as the image of a goddess. As a beautiful "trophy", she has become a symbol of power in the bilateral battle for wars and lacks her independent narrative value.

Coincidentally, Blade Runner released in 1982 is an important work that cannot be ignored in the history of science fiction films. In this film, science and technology are able to create an artificial human being which is known as a 'Replicant'. It can be said that compared to Star Wars that occurred in outer space, Blade Runner more focuses on the future situation of the planet earth and mankind, which is an allegory to the present social reality. Many social issues such as energy crisis and scientific ethics were discussed in the film [5]. Ironically, even in such a developed context, the main female character in this film is a replicant without individual characters. In the illusion of the future, Blade Runner does make efforts to portray a new woman of the future. Instead, it gathers all the requirements of men for women into the look of a dream lover. Rachael the replicant is the embodiment of this fantasy incarnation: she is young and beautiful, with gentle character and an extremely attractive body figure. Her existing is not only to satisfy the actor's fantasies about the perfect lover but also the audience's. The image of this "Dream Lover" was continued by the series. In the sequel Blade Runner 2049 released in 2017, another image of a perfect girlfriend was born. She was not even a human being. She was just a virtual projection. She can transform different dresses as the male character needs. This virtual projection girlfriend becomes a more dependable, more attractive decoration that satisfies the expectation of male audiences.

There is a sense of distance between these female characters and female audiences. Those roles are the images which follow the description of stereotype. They are neither accurate nor representative. In fact, the role of women in society and family has changed. Some women are no longer comfortable with just being housewives but are willing to enter the workplace more independently and compete fairly with men [6]. At the same time, the second wave of feminism began to call for improving the status of women in all aspects 
of life, such as equality in the division of labour at home. And these "doll" female characters apparently cannot satisfy the audiences. The audiences call for more realistic characters who are no longer the followers of male characters. Although in reality, according to [7], women still have to spend more time on housework than their spouses; and in the workplace, they also have to face gender bias. Compared with such a harsh reality, science fiction films are continually shaping the models of new and independent women: some of them regard their careers and their families as equally necessary; some of them take on leadership roles and compete with men in the workplace. Instead of using the traditional way to describe female characters' social status and career choices, science fiction films present a more extensive range of exciting possibilities and encourage female audiences to make more diversified choices. Science fiction films explore and challenge the value boundaries of female characters, attempt to change the limitations and break the stereotypes [8].

After entering the $21 \mathrm{st}$ century, these voices from the feminist were finally heard by filmmakers. They began to understand that the audiences expect to see diversity in independent female images. The science fiction films of this period began to be influenced by post-structuralism feminism [2].

Since the relationship between films and the real world is inseparable, the audience can find the mapping of actual events and critiques of social issues in films and other works of art. Similarly, films will also bring about changes in reality and the emergence of a new trend of thought. This is a definite process of mutual interaction. [9] may agree with this statement; he mentions that the prosperity of sci-fi works in the British society is because the audience needs this science fiction content to help them to respond to political issues and the real situation. Nowadays, many films begin to tell the story of female characters, giving them an independent personality, and let these female characters participate in the development of the plots, and even lead the story. These films have a definite positive impact on breaking the social stereotypes. They encourage women to enrich their lives and increase their social effects. Since then, the film production has also moved closer to this trend.

In 2009, the film Avatar described the story of an alien planet. As the leading role in the film, Naytiri, a Naami princess and a warrior, is tall and muscled. She fights for the rights for her kind and justice, like many other female soldiers described in this film. These images are no longer just a single representation of young, beautiful, and idealised woman, but display mature roles full of strength and knowledge. Avatar does not emphasise their gender but focuses on expressing their kindness and wisdom and resisting the spirit of authority.

After this period, female scientists seem to have become indispensable elements in science fiction films. The main plot of Interplanetary Crossing released in 2014 was the adventure of a female pilot Amelia, and the puzzle-solving story of a female scientist Murphy. And in Arrival (2017), the linguist Louise, as the protagonist, took the lead in the story of dealing with extraterrestrials. Eventually, she resolved unnecessary wars and solved problems for all humanity. It can be said that Louise is a non-traditional heroine, who can overcome all difficulties independently without the help of a hero.

The research of [2] points out that television series, novel, and films can influence people's interpersonal relationships and perceptions. In other words, the content of films could help to promote the discourse of gender equality in the field of science in reality. Therefore, examining gender relations and gender expressions in the films can help to understand these social trends of thought and to accept new ideas.

Ref. [3] and [10] are in agreement with that idea. [11] finds in his research that science fiction films could help students to have a better understanding and participate in science education. Many female students who are traditionally considered to be unsuccessful in science studying can also acquire knowledge from science fiction films and thus stimulate their interest in science. And [3] clearly state that due to the influence of science fiction films, more women chose to enter the scientific industry. Since the beginning of the new century, the proportion of women working as laboratory technicians and scientists has increased significantly [12], and they have been more or less encouraged by the image of female scientists in science fiction films and eventually decided to devote themselves to scientific research. This is a case in which science fiction films actively promote the participation of women in the field of science.

With the development of science, the current society has become more and more similar to the ideal society in early sci-fi films. However, the advance of technology and the progress of idea are not the same. Long-standing stereotypes have still impeded women's expression of equality. Although there are also limitations exist, the filmmakers of sci-fi films do actively challenge the gender relations in the new era and embrace the influence of feminist ideological trends to represent real female roles and explore the future of gender issues. They break down the conventional framework and redefine the female characters in science fiction films under the text of the new generation.

From the above examples, it can be seen that as time goes by, the description of female characters in sci-fi films has become more diversified: women are no longer the beautiful, obsessive products, but more realistic and independent. They come from different age groups and are engaged in various jobs. Those characters begin to fall away from male's control. These changes have responded to the more tolerant reality of society for women. On the other hand, they also set expectations for the future under the setting of science fiction themes.

\section{The Limitation of SCIENCE FICTION ON REPRESENTING FEMALE IMAGES}

Science fiction films also have deficiencies in shaping female characters. The audience is looking forward to seeing their role in science fiction films instead of just being a viewer and an outsider of other people's stories. That require sci-fi films show a variety of female images, which can be representative widely. For example, these roles should not only be the ladies who have a noble status, but they should come from all levels in this society and have different 
occupations with different skin colours [7]. Science fiction films more focused on demonstrating well-educated women from the upper class with perfect jobs. Filmmakers try to please women with high consumption capacity but ignore the others. Those characters and audiences do not represent the majority of the population in this society. By contrast, male roles in science fiction films are more grass-roots. Furthermore, western mainstream sci-fi films lack attention to minority groups such as black and Asian women [6]. The whiteness in science fiction film is apparent. There are still shortcomings in the expression of diversity in there. However the lack of comprehensive representation is also one of the manifestations of inequality.

Secondly, men still play the dominant role in the majority of science fiction films. Although the audience is gratified to see more women engaged in scientific careers, the proportion of female roles is slightly inferior to that of men. These female characters are often surrounded by male colleagues or other members, and their narrative components are inevitably doped with male influences on them. Even in the science fiction films which are actively creating gender equality, there are few examples that women are truly independent.

In addition to the flaws of the films themselves, the impact of this genre of science fiction is still slightly inadequate to the audience. Science fiction is not the mainstream in today's film market. Compared to other genres such as action, romance, and comedies, the total number of productions of science fiction films is much smaller [13]. Box office sometimes shows the influential power of one particular film: it not only represents the number and the ranges of audiences this film can reach but also becomes a standard to judge if this film a successful commercial product or not. The economic profits one genre can make will also affect the willingness of the film industry about production. Therefore, sci-fi films always need to combine other popular Hollywood elements of actions, adventures and heroes to win a good box office. Those elements are thought as primarily masculine. This is why sometimes sci-fi filmmakers will ignore the demands of female audiences.

Additionally, [14] believes that audiences of different sexes have different tastes for films. According to his research, it can be seen that women only account for $35 \%$ of the total number of science fiction audiences, which makes them not the primary target audience for this type of film. He also points out that science fiction films are male-themed films, which are less attractive to women than family films, romantic comedies, and musicals. It suggests that if science fiction films want to break the old model of gender and have a broader impact in society, they also need to expand the scale of production and attract more potential audiences of both genders.

However, the masculinity of science fiction films is related to its situation in the film industry. According to [11], the number of female directors who direct sci-fi films is relatively small, and most of their work is low-budget films, which is difficult to attract the audience. Meanwhile, according to the statistics of "Sci-Fi Features Directed by Women" on IMDB, these works created by female directors rarely get 7 out of 10 (which means good) in the spontaneous evaluation of the Internet users; on the contrary, there are many 3-point films appear in this statistic, they are far below the average quality. These cheap, rough sci-fi movies seldom tell stories and display social relationship seriously. The audience cannot expect to get entertainment from these shoddy films, and also absolutely cannot be educated by them. Of course, this situation is not just in science fiction films. Of the top 100 grossing movies in 2017 , only $8 \%$ of them were directed by women. In the mainstream film industry, the proportion of female directors is still a tiny part of the total number.

\section{CONCLUSION}

Although science fiction films are not perfect, it is undeniable that they are actively exploring the positioning of female characters and present a large number of outstanding professional women. With the performance and encouragement of these positive roles, modern women are more determined to engage in science or study science majors. This is how cultural phenomena have impacted social reality. What is gratifying is that there are still more opportunities for science fiction films to improve the description of female characters, and to present more diverse and vivid images of female roles to influence more audiences.

\section{REFERENCES}

[1] V. Hollinger, "(Re)reading queerly: Science fiction, feminism, and the defamiliarization of gender," Science Fiction Studies, March 1999.

[2] J. Chamarette, "Embodied worlds and situated bodies: Feminism, phenomenology, film theory," Journal of Women in Culture and Society, vol. 40, pp. 289-295, 2015

[3] L. Orthia and R. Morgain, "The gendered culture of scientific competence: A study of scientist characters in doctor who 1963-2013,' Sex Roles, pp. 79-94, March 2016.

[4] S. Marilley, Woman Suffrage and the Origins of Liberal Feminism in the United States, 1820-1920, Cambridge: Harvard University Press, January 2014.

[5] P. Ruppert, "Blade runner: The utopian dialectics of science fiction films," Cineaste, vol. 17. pp. 8-13. 1989.

[6] J. Sutherland and K. Feltey, "Here's looking at her: An intersectional analysis of women, power and feminism in film," Journal of Gender Studies, pp. 618-631, May 2015.

[7] K. McGinn and E. Oh, "Gender, social class, and women's employment," Current Opinion in Psychology, pp. 84-88, December 2017.

[8] V. Hollinger, "Feminist science fiction: Breaking up the subject," Extrapolation, vol. 31, 1990.

[9] H. O'Connell, “The British science fiction boom: Tracking the currents of the Future between postimperialism, postnationalism, and globalization: Editorial introduction," The New Centennial Review, pp. 1-12, March 2016.

[10] H. Surmeli, "Examination the effect of science fiction films on science education students' attitudes towards STS course," Procedia - Social and Behavioral Sciences, vol. 47, pp. 1012-1016, June 2012.

[11] A. Billson. (November 2018). The final frontier: How female directors broke into Sci-fi. The Guardian. [Online]. Available: https://www.theguardian.com/film/2018/mar/16/female-directors-scie nce-fiction-sci-fi-patty-jenkins-ava-duvernay

[12] M. Frize, The Bold and the Brave, Ottawa: University of Ottawa Press, 2010, pp. 1-31.

[13] M, Barnett, H. Wagner et al., "Science, fiction, and film: A study of the interaction of science, science fiction literature, and the growth of cinema," Journal of Science Education and Technology, vol. 15, April 2006.

[14] N. Redfern, "Correspondence analysis of genre preferences in UK film audiences," Journal of Audience and Reception Studies, pp. 45-55, November 2012. 


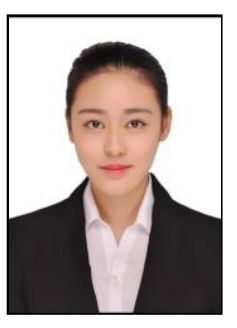

Wenjia Tang was born in Chengdu, China on June 12

1996. She is a master student at the Department of Film

Studies, University College London (2018-2019). Her

research focuses on issues of gender studies, media and globalisation, and online stream TV. 